\title{
Sosiaalilääketiede: mitä se on ja mihin menossa?
}

\author{
RIIKKA LÄMSÄ, VELI-MATTI PARTANEN
}

Sosiaalilääketieteen yhdistys on päässyt kunnioitettavaan 50 vuoden ikään. Suomessa on suuri joukko ansioituneita henkilöitä, jotka ovat edistäneet sosiaalilääketieteellistä tutkimusta ja sosiaalilääketieteen näkyvyyttä yhteiskunnassa, ajaneet sosiaalilääketieteelle tärkeitä asioita ja toimineet Sosiaalilääketieteen yhdistyksen hyväksi. Väitöskirjansa sosiaalilääketieteen muotoutumisesta 1800-luvun lopulta 2000-luvun vaihteeseen tehnyt Ranja Aukee (2013) teki vuonna 1999 Sosiaalilääketieteen yhdistyksen jäsenille kyselyn, jossa muun muassa pyydettiin nimeämään merkittäviä sosiaalilääketieteilijöitä. Listaan päätyi 12 sosiaalilääketieteilijää (taulukko 1), jotka edustivat eri tutkimusaloja ja -aiheita. Kaikki olivat luoneet merkittävän tutkijanuran ja edistäneet sosiaalilääketieteelle tärkeitä asioita tieteellisellä tai muilla yhteiskunnallisilla areenoilla. (Aukee 2013.) Sosiaalilääketieteen yhdistyksen juhlavuoden kunniaksi päätimme ottaa yhteyttä näihin sosiaalilääketieteilijöihin ja kysyä mitä sosiaalilääketiede heidän mielestään on, mistä se on tulossa ja mihin menossa. Saimme kasvokkaisen ryhmähaastattelun ja sähköpostivastausten kautta näkemyksiä yhteensä kuudelta sosiaalilääketieteilijältä: Elina Hemmingiltä, Jussi Huttuselta, Antti Karistolta, Eero Lahelmalta, Pekka Puskalta ja Antti Uutelalta.

\section{SOSIAALILÄÄKETIEDE TIETEENÄ}

Sosiaalilääketiedettä määriteltiin usealla eri tavalla. Kariston mukaan sosiaalilääketieteessä tutkitaan terveyttä ja sairauksia (terveys- ja sairauskäyttäytymistä) sosiaalisissa yhteyksissään, esimerkiksi sairastavuuden sosiaalisia eroja. Sairauden hän ymmärtää tautia laajemmin: sosiaalilääketieteessä on kiinnostuttu myös ihmisten sairauskokemuksista ja sairauksien sosiaalisista kytkennöistä. Myös Lahelman määritelmä sosiaa- lilääketieteelle korostaa sosiaalista ulottuvuutta, joka sisältää esimerkiksi sosiaalisen aseman, sosiaaliset suhteet ja sukupuolen sekä iän sosiaalisessa mielessä erotuksena kansanterveystieteestä, joka pitää sisällään paitsi sosiaalisen ulottuvuuden myös hygienian ja ympäristökysymykset. Puskan määritelmässä on aikaulottuvuus: aikaisemmin sosiaalilääketiede oli kiinnostunut ongelmaryhmien kuten alkoholistien terveysasioista, mutta nykypäivänä se käsittelee laajemmin sosiaalisten tekijöiden vaikutusta terveyteen.

Hemminki perusti sosiaalilääketieteen määritelmänsä lääketieteen kolmijakoon: biolääketieteeseen, kliiniseen lääketieteeseen ja sosiaalilääketieteeseen. Huttunen näki sosiaalilääketieteen pitkälti yhteneväisenä kansanterveystieteen kanssa ja sisällytti siihen myös sosiaali- ja terveydenhuollon palvelujärjestelmän kysymykset. Myös Uutela näki sosiaalilääketieteen kansanterveystieteenä, joka kohdistuu interventioihin huonoosaisten aseman parantamiseksi.

Jos sosiaalilääketieteen määritelmää lähestyy eri tieteenalojen kautta, niin listasta muodostuu pitkä: ainakin lääketiede, erityisesti kansanterveystiede ja epidemiologia; sosiaalitieteet, erityisesti sosiologia ja sosiaalipolitiikka; terveyspsykologia ja sosiaalipsykologia; kasvatustiede; terveydenhuollon tutkimus ja ravitsemustiede mahtuvat sosiaalilääketieteen monitieteisen tutkimuskentän alle.

Sosiaalilääketieteen arvoista sosiaalilääketieteilijät olivat hyvin saman mielisiä. Terveys ymmärrettynä toimintakykynä, elinvoimana ja terveyden edistämisenä on sosiaalilääketieteen yksi keskeinen arvo. Sosiaalilääketiedettä kuvaa pyrkimys terveyden edistämiseen, oikeudenmukaisuuteen ja tasa-arvoon (vastakohtana eriarvoisuudelle) ja se pitää sisällään sosiaalisen vastuun huono-osaisista. 
Taulukko 1: Merkittäviä sosiaalilääketieteilijöitä Aukeen (2013) tutkimuksen mukaan.

\begin{tabular}{|c|c|c|}
\hline Nimi & Tieteenala & Ura \\
\hline $\begin{array}{l}\text { Seppo Aro } \\
(1948-1997)\end{array}$ & $\begin{array}{l}\text { Lääketiede, } \\
\text { sosiaalipolitiikka }\end{array}$ & $\begin{array}{l}\text { - Väitteli tohtoriksi epidemiologiasta Tampereen yliopistossa. } \\
\text { - Toimi lääkintöhallituksessa, sittemmin } \\
\text { Kansanterveyslaitoksessa ja Stakesissa } \\
\text { terveydenhuoltotutkimuksen tutkijana ja johtajana. } \\
\text { - Tutki terveydenhuollon oikeudenmukaisuutta. } \\
\text { - Merkittävä rooli Sosiaalilääketieteellisessä yhdistyksessä } \\
\text { ja Sosiaalilääketieteellisessä aikakauslehdessä, Euroopan } \\
\text { kansanterveysjärjestön perustajajäsen. }\end{array}$ \\
\hline $\begin{array}{l}\text { Jeddi Hasan } \\
(1931-2003)\end{array}$ & Lääketiede & $\begin{array}{l}\text { - Väitteli lääketieteen ja kirurgian tohtoriksi Tampereen } \\
\text { yliopistossa. } \\
\text { - Toimi Työterveyslaitoksen toksikologian ja säteilybiologian } \\
\text { jaoksen johtajana, Jyväskylän yliopiston liikuntahygienian } \\
\text { ja kansanterveyden professorina, Tampereen yliopiston } \\
\text { työterveyden professorina. } \\
\text { - Tutki sosiaalisten olosuhteiden ja biologian suhdetta ja } \\
\text { terveyden eriarvoista jakautumista. }\end{array}$ \\
\hline $\begin{array}{l}\text { Elina Hemminki } \\
(1948-)\end{array}$ & Lääketiede & $\begin{array}{l}\text { - Aloitanut kansanterveystieteen parissa jo toisen vuoden } \\
\text { lääkäriopiskelijana, väitellyt Tampereen yliopistossa. } \\
\text { - Työskennellyt tutkijana ja opettajana yliopistoissa ja } \\
\text { tutkimuslaitoksissa Suomessa ja ulkomailla. Toiminut } \\
\text { virkamiehenä Lääkintöhallituksessa ja Sosiaali- ja } \\
\text { terveyshallituksessa ja tutkijana Stakesissa, THL:ssä ja } \\
\text { Suomen Akatemian tutkijatoimissa. } \\
\text { - Tutkinut terveydenhuoltoa, tutkimus- ja lääkepolitiikkaa sekä } \\
\text { lääketieteellisen teknologian käyttöä ja seurauksia erityisesti } \\
\text { lisääntymisterveyspalveluissa. }\end{array}$ \\
\hline $\begin{array}{l}\text { Jussi Huttunen } \\
\text { (1941-) }\end{array}$ & Lääketiede & $\begin{array}{l}\text { - Väitellyt Lääketieteellisen kemian laitokselta, josta jatkoi yli } \\
\text { kahdeksi vuodeksi Yhdysvaltoihin. } \\
\text { - Toiminut sisätautilääkärinä ja Kuopiossa sisätautien } \\
\text { professorina, josta siirtynyt Kansanterveyslaboratorioon ja } \\
\text { edelleen Kansanterveyslaitokseen, joka pääjohtajana toiminut } \\
\text { vuodet ennen eläkkeelle jäämistään. } \\
\text { - Työskennellyt sosiaali- ja terveysministeriössä } \\
\text { osastopäällikkönä. } \\
\text { - Tutkijan uralla tehnyt tutkimusta endokrinologiasta, } \\
\text { diabeteksesta, ravitsemusepidemiologiaa ja myöhempinä } \\
\text { vuosina tutkinut eriarvoisuutta ja palvelujärjestelmää. }\end{array}$ \\
\hline $\begin{array}{l}\text { Antti Karisto } \\
(1951-)\end{array}$ & Yhteiskuntapolitiikka & $\begin{array}{l}\text { - Työskennellyt sosiaalipolitiikan assistenttina ja Kelan } \\
\text { tutkimuslaitoksen tutkijana, Helsingin kaupungin } \\
\text { sosiaaliviraston kehittämispäällikkönä ja Helsingin } \\
\text { kaupungin tietokeskuksen tutkimuspäällikkönä ja } \\
\text { kaupunkitutkimusyksikön vetäjänä. } \\
\text { - Toiminut Helsingin yliopiston sosiaalipolitiikan, erityisesti } \\
\text { sosiaalityön professorina ja sosiaaligerontologian professorina. } \\
\text { - Tutkinut terveyden sosioekonomisia eroja, työterveyshuoltoa, } \\
\text { terveyskäyttäytymistä, ns. kolmatta ikää ja vanhenemista. }\end{array}$ \\
\hline $\begin{array}{l}\text { Eero Lahelma } \\
(1947-)\end{array}$ & $\begin{array}{l}\text { Terveyssosiologia, } \\
\text { kansanterveystiede }\end{array}$ & $\begin{array}{l}\text { - Väitellyt valtiotieteiden tohtoriksi Helsingin yliopistossa. } \\
\text { - Työskennellyt tutkijana Alkoholitutkimussäätiössä, } \\
\text { Kuntoutussäätiössä ja Suomen Akatemiassa sekä } \\
\text { lääketieteellisen sosiologian professorina Helsingin yliopiston } \\
\text { lääketieteellisessä tiedekunnassa. } \\
\text { - Tutkinut terveyden sosioekonomisia eroja Suomessa ja muissa } \\
\text { maissa, sekä työn, työttömyyden ja terveyden välisiä suhteita. }\end{array}$ \\
\hline
\end{tabular}




\begin{tabular}{|c|c|c|}
\hline Nimi & Tieteenala & Ura \\
\hline $\begin{array}{l}\text { Tapani Purola } \\
(1929-2015)\end{array}$ & Sosiaalipolitiikka & $\begin{array}{l}\text { - Väitteli väestöpoliittisella, maassamuutoa käsittelevällä } \\
\text { tutkimuksella. } \\
\text { - Johti Kelassa sairausvakuutuksen seurantatutkimusta, toiminut } \\
\text { sosiaali- ja terveysministeriössä suunnittelupäällikkönä, } \\
\text { Helsingin yliopiston sosiaalipolitiikan professorina ja } \\
\text { esimiehenä. } \\
\text { - Tutki sairaus- ja sosiaalivakuutusta. Loi ns. Purolan mallin } \\
\text { sairauden ja palvelujen käytön yhteydestä luonnon- ja } \\
\text { sosiaaliseen järjestelmään, yhteiskunnan rakenteisiin ja } \\
\text { kulttuuriin. }\end{array}$ \\
\hline $\begin{array}{l}\text { Pekka Puska } \\
(1945-)\end{array}$ & $\begin{array}{l}\text { Lääketiede, } \\
\text { valtiotieteet }\end{array}$ & $\begin{array}{l}\text { - Väitellyt lääketieteen ja kirurgian tohtoriksi Kuopion } \\
\text { yliopistossa. } \\
\text { - Toiminut Pohjois-Karjala projektin päätutkijana, } \\
\text { kansanterveyslaitoksen osastonjohtajana, WHOn } \\
\text { tarttumattomien tautien ehkäisyn ja terveyden edistämisen } \\
\text { johtajana, THL:n pääjohtajana ja nykyisin kansanedustajana. } \\
\text { - Tutkinut kansantautien epidemiologiaa ja ehkäisyä sekä } \\
\text { terveyden edistämistä. }\end{array}$ \\
\hline $\begin{array}{l}\text { Konrad } \\
\text { ReijoWaara } \\
(1853-1936)\end{array}$ & Lääketiede & $\begin{array}{l}\text { - Väitöskirja “Terveyshoidollisia tutkimuksia Haapajärven } \\
\text { piirilääkäripiiristä”. } \\
\text { - Toimi piirilääkärinä ja Terveydenhuoltolehden ja Duodecimin } \\
\text { päätoimittajana. } \\
\text { - Kehitti terveysvalistajana kansan terveydellisiä oloja, julkaisi } \\
\text { yli tuhat kansantajuista kirjoitusta terveydestä ja sairauksien } \\
\text { hoidosta. Ehdotti tuberkuloosiparantoloiden perustamista. }\end{array}$ \\
\hline $\begin{array}{l}\text { Matti Rimpelä } \\
(1942-)\end{array}$ & $\begin{array}{l}\text { Lääketiede, } \\
\text { sosiologia }\end{array}$ & $\begin{array}{l}\text { - Väitteli lääketieteen ja kirurgian tohtoriksi Tampereen } \\
\text { yliopistossa. } \\
\text { - Toiminut lääkintöhallituksen ylilääkärinä, lääketieteellisen } \\
\text { sosiologian apulaisprofessorina Helsingin yliopistossa, } \\
\text { ylilääkärinä terveydenhuollon oikeusturvakeskuksessa, } \\
\text { tutkimusprofessorina Stakesissa ja terveystieteiden } \\
\text { professorina Tampereen yliopistossa. } \\
\text { - Tutkinut nuorten terveyttä, tupakka- ja terveyspolitiikkaa, } \\
\text { perusterveydenhuoltoa. }\end{array}$ \\
\hline Antti Uutela & Sosiaalipsykologia & $\begin{array}{l}\text { - Väitellyt valtiotieteiden tohtoriksi Helsingin yliopistossa. } \\
\text { - Tehnyt uran Helsingin yliopistossa opettajana ja } \\
\text { apulaisprofessorina, Kansanterveyslaitoksessa } \\
\text { tutkimusprofessorina ja osastonjohtajana ja Tampereen } \\
\text { yliopistossa osa- ja määräaikaisena kansanterveystieteen } \\
\text { professorina. } \\
\text { - Tutkinut terveyskäyttäytymistä, sosioekonomisia terveyseroja } \\
\text { ja ravitsemusinterventioita. }\end{array}$ \\
\hline $\begin{array}{l}\text { Tapani Valkonen } \\
(1941-)\end{array}$ & $\begin{array}{l}\text { Sosiologia, } \\
\text { väestötiede }\end{array}$ & $\begin{array}{l}\text { - Väitellyt tohtoriksi sosiologiasta Helsingin yliopistossa, } \\
\text { väitöskirja käsitteli yhteisön vaikutusta yksilöön ja sen } \\
\text { tutkimista. } \\
\text { - Toiminut väestötieteen professorina, kaupunkisosiologian } \\
\text { professorina, valtiotieteellisen tiedekunnan dekaanina } \\
\text { Helsingin yliopistossa. } \\
\text { - Kehittänyt väestötieteen tutkimusmenetelmiä, tutkinut } \\
\text { muuttoliikettä ja kuolleisuuden sosioekonomisia eroja. }\end{array}$ \\
\hline
\end{tabular}


Kiinnostavaa keskustelua käytiin sosiaalilääketieteen perusperiaatteesta. Hemminki näki perusperiaatteena sosiaalisen merkityksen terveydessä ja terveydenhuollossa (sosiaalinen esimerkiksi eriarvoisuutta tuottavana). Lahelma oli samaa mieltä, mutta laajensi sosiaalista myös sairastumisen seurauksiin. Sairaus ja sen aiheuttamat rajoitukset aiheuttavat yksilölle vaikeuksia selviytyä työssä ja sosiaalisissa ympäristöissä. Lahelma piti sosiaalilääketieteen vahvuutena sitä, ettei sen sisällä ole tarvetta valita suuntautuuko puhtaasti akateemiseen tutkimukseen vai käytäntöön vai jopa toimeenpanijoiden kuten poliitikkojen suuntaan. Yleisenä motiivina on kuitenkin aina pyrkimys ihmisten, ihmisryhmien, väestöjen parempaan terveyteen. Tästä Hemminki oli samaa mieltä ja painotti, että sosiaalilääketieteen intressinä eivät ole yhden ihmisen kokemukset, joista lääkäri on taas kliinisessä työssään kiinnostunut. Lahelma muistutti kuitenkin, että on hyvä tutkia asioita eri puolilta ja myös yksilötason tai pienten joukkojen tutkimus voi olla tärkeää: niiden avulla voidaan testata määrällisten tutkimusten löydöksiä ja toisaalta ne tuottavat hypoteeseja kattaville määrällisille tutkimuksille.

\section{SOSIAALILÄÄKETIETEEN SAAVUTUKSET}

Viimeisen sadan vuoden aikana tapahtuneen terveyskehityksen voi Huttusen mukaan jakaa kolmeen jaksoon, joista sosiaalilääketiede on vaikuttanut kahteen ensimmäiseen. Ensimmäiselle jaksolle 1950-luvulle asti oli leimallista kehitys asuinoloissa, ravitsemuksessa ja hygieniassa. 1950-1990-luvuilla taas tapahtui kehitystä terveyden edistämisessä, kuten sepelvaltimotautien hallinnassa. Tällä hetkellä elämme kolmatta vaihetta, jossa terveyden riskitekijät eivät ole juuri muuttuneet, mutta elinajanodote kuitenkin pitenee. Osittain tämä johtuu aiemmista muutoksista, mutta yhä enemmän se on teknologian ansiota. Huttunen pyytääkin usein esityksiä pitäessään yleisöä laskemaan, kuinka monta kertaa heidän elämänsä on pelastunut teknologian ansiosta. Useimmilla varttuneemmasta väestä ainakin muutama kerta tulee nopeasti mieleen.

Sosiaalilääketieteen olemassaolon aikana huomio on kiinnittynyt pääasiassa väestön terveyseroihin keskeisiin elintapoihin, mutta parannusta on tapahtunut myös esimerkiksi liikenneonnettomuuksien ja työtapaturmien vähenemisessä. Lahelma mainitsi merkittävänä saavutuksena myös sen, että väestöryhmien väliset terveyserot on tiedostettu ja kansanterveysohjelmissa tähdätään erojen kaventamiseen, joskaan erot eivät ole toistaiseksi kaventuneet toivotulla tavalla.

Karisto antoi kiitosta sosiaalilääketieteen pioneereille, kuten piirilääkäreille ja tutkijoille, jotka huomasivat sairastavuuden sosiaalisen sidonnaisuuden. Samaan tapaan Hemminki kuvasi sosiaalilääketieteen toimijoiden ansioksi sen, että he tuottivat tietoa suurista yhteiskunnallisista ongelmista ja pystyivät samalla ehdottamaan miten ongelmiin pitäisi puuttua. 1970-luvun alussa hyväksytty kansanterveyslaki toimii esimerkkinä laajasta ymmärryksestä, jossa potilasnäkökulman lisäksi terveyteen vaikuttaviksi tekijöiksi liitettiin myös ympäristö ja sosiaalinen tilanne. Sosiaalilääketieteilijät auttoivatkin määrittelemään terveyspolitiikan osana yhteiskuntapolitiikkaa ja lisäämään ymmärrystä, että terveyteen voitiin vaikuttaa elinoloja kohentamalla.

\section{TULEVAISUUDEN HAASTEET}

Terveyspoliittisia haasteita ja kiinnostavia tutkimuskohteita löytyi haastateltavilta helposti. Miten huolehtia siitä, että teknologian kehitys ei synnytä uutta eriarvoisuutta? Miten kehittää palvelujärjestelmää siten, että se olisi väestön ikääntyessä ja palvelutarpeen kasvaessa mahdollisimman vaikuttava ja turvaisi hyvän hoidon ja hoivan resurssien rajallisuudesta huolimatta? Myös terveyskäyttäytymisen kohentamiseen pitäisi edelleen keskittyä, sillä elintavat ovat kroonisten sairauksien kannalta olennaisia. Globaaleilla tapahtumilla on myös yhä enemmän merkitystä ja erilaiset taloudelliset intressitahot ovat aiempaa voimakkaampia, jolloin sääntely on ongelmallisempaa. Terveyserojen kaventamisessa on kyse laajasti elinoloista, elintavoista ja yhteiskunnan kehityksestä. Lahelma nosti keskeiseksi kysymykseksi, miten maahanmuuttajat asettuvat suomalaiseen yhteiskuntaan ja syntyykö sen myötä uusia eriarvoistavia jakolinjoja. Karisto peräänkuulutti kulttuurista sairauskokemusten tutkimusta, postgoffmanilaista sairaalasosiologiaa tai muuta terveydenhuollon instituutioiden tutkimusta ja tulevan sote-uudistuksen seurausten tutkimista.

Sosiaalilääketieteilijöiden tulevaisuuskuva oli hieman pessimistinen. 1970- ja 1980-luvuilla vallinnut vahva kansanliike väestön terveyden edis- 
tämiseksi on Huttusen mukaan unohtumassa. Huttunen kaipasi Martti Karvosen, Pekka Puskan ja Kalevi Pyörälän jalanjäljissä kulkevia tulisieluisia sosiaalilääketieteilijöitä, jotka paitsi tuottaisivat tietoa myös saattaisivat sen päättäjien pöydille. Hemmingin mukaan nykytutkijoilta puuttuu sisäinen palo, mutta arveli ilmiön olevan globaali. Joka tapauksessa sosiaalilääketieteilijät kannustivat nuorempia tutkijoita: Vaikka tutkijan uraan liittyy monenlaisia epävarmuuksia, niin "ajatelkaa suuria ja tehkää rohkeasti yhteistyötä eri tutkijoiden kanssa niin Suomessa kuin ulkomaillakin”. Lahelma piti Sosiaalilääketieteen yhdistyksessä toimimista merkittävänä asiana omalla urallaan ja kehotti nuoria tutkijoita lähtemään mukaan yhdistyksen toimintaan.

\section{LOPUKSI}

Aukee (2013) kuvasi "uuden sosiaalilääketieteen" luomista1960-70-luvuillayhteiskuntapoliittiseksi projektiksi, jonka keskiössä olivat uusi terveys- ja tiedepolitiikka, sosiologian ja muiden yhteiskunta- ja kulttuuritieteiden mukaantulo terveystutkimukseen, sosiaalilääketieteen kriittinen ja radikaali perinne sekä Sosiaalilääketieteen yhdistys ry. Uusi sosiaalilääketiede määrittyi monitieteiseksi ja sen perusarvoja olivat oikeudenmukaisuus ja tasa-arvo. Tähän kirjoitukseen kuultujen vaikut- tajien näkemys sosiaalilääketieteestä on hyvin samantapainen, joten voi sanoa, että elämme edelleen uuden sosiaalilääketieteen aikaa. Esimerkiksi kysymys terveyden eriarvoisuudesta on yhä vain ajankohtainen. Kuitenkin yhdistyksen ensimmäisen 50-vuotistaipaleen kunniaksi ja tulevan 50vuotistaipaleen aloittamiseksi tarjoamme lukijoille tulevaisuutta koskevan ajatusleikin: mitkä ovat ne yhteiskunnalliset ja globaalit ilmiöt, epäkohdat ja vahvuudet ja sosiaalilääketieteen tutkimusja vaikuttamistavat, jotka vievät meidät sosiaalilääketiede 2.0:aan?

\section{LÄHDE}

Aukee, Ranja (2013) Vanhasta uuteen sosiaalilääketieteeseen. Suomalaisen sosiaalilääketieteen muotoutuminen 1800-luvun lopulta vuosituhannen vaihteeseen. Acta Universitatis Tamperensis 1825. Tampere: Tampereen yliopisto.

\section{RIIKKA LÄMSÄ \\ VTT, sh, erikoistutkija \\ Terveyden ja hyvinvoinnin laitos \\ Mielenterveysyksikkö}

Veli-Matti Partanen

$T t M$, väitöskirjatutkija

Suomen Syöpärekisteri 